\title{
THE COMPARATIVE STUDY BETWEEN THE EFFECT OF COVID-19 AND EARTHQUAKE DISASTER ON TOURISM ATTRACTION IN YOGYAKARTA
}

\author{
Yohanes Meindra Prakoso ${ }^{1}$, Boris Ramadhika ${ }^{2}$ \\ Tidar University, Indonesia \\ meindray016@gmail.com
}

\begin{abstract}
COVID-19 and earthquake disaster both give effect in Tourism Attraction, then in this study will compare the difference impact between COVID-19 and earthquake disaster, especially in Yogyakarta. This study deals with the hospitality industry condition during Corona Virus Disease (COVID-19) and earthquake disaster in Yogyakarta 2006. This study is to seek an answer to these two research questions: 1. What is the effect of the COVID-19 virus on Tourism Attraction in Yogyakarta? 2. Is the impact of the COVID-19 virus on Tourism attractions in Yogyakarta has a more severe impact than an earthquake in 2006? From the results of this study, it was found that COVID-19 is more dangerous than earthquakes, particularly in the economy sector. The method used in this study is a descriptive qualitative method; the problem that can be investigated by qualitative descriptive research refers to quantitative studies, comparative studies (comparisons). The data to support this study was taken from journals, books, websites, government documents, and any other sources or articles.
\end{abstract}

Keywords: COVID-19; Earthquake; Yogyakarta Tourism.

\section{INTRODUCTION}

In December 2019, a mysterious case of pneumonia first reported in Wuhan, Hubei Province (Huang et al., 2020). Source transmission of this case is still unknown; however, the first case was linked to the fish market in Wuhan December 18 to December 29, 2019, there were five patients treated with Acute Respiratory Distress Syndrome (ARDS). From December 31, 2019, to January 3, 2020, this case is increasing rapidly, marked by 44 cases were reported. Not until one month, this disease has spread in various provinces, others in China, Thailand, Japan, and South Korea.

This virus can be transmitted from human to human and has spread widely in China and more than 190 other countries and territories. On March 12, 2020, WHO announced COVID-19 as a pandemic. The number of cases and death due to the spread of the COVID-19 in the world has not shown signs of decline. Launching data from the Worldometers website, the total number of COVID-19 cases in the world has been confirmed as many as 7,311,062 (7.3 million) cases as of Wednesday (6/10/2020) morning. Of these, as many as 3,594,227 (3.5 million) 
patients were cured, 412,993 people died. Active cases to date have been recorded as 3,303,842, with details of 3,249,902 patients with mild conditions and 53,940 in serious conditions. Whereas in Indonesia, the first COVID-19 case was reported on March 2, 2020, in a number of two cases. Data from June 6, 2020, shows that there were 34,316 confirmed cases and 1,959 death cases.

To stop the broader spread of COVID-19, governments throughout the world forbid travel between countries or cities, and the government also recommends to Work From Home (WFH), in this way, transmission or spread of COVID-19 can be reduced. But on the other hand, some deficiencies are quite affected, one of them is in the tourism industry. This happens because the tourism industry cannot work, walking alone without guests come. Then, tourism businesses think hard about how to stay afloat. Non-star hotels, due to the COVID-19 outbreak, chose to take a short vacation with all its employees. Instead of having to bear an operational burden too significant, while tourist visits are almost non-existent at all. Then for hotels that are still operating, make a rotating work system for employees and reduce the amount in each working shift. The work system takes turns by managing the work time of the employees. Like 15 working days, 15 days off. The number of employees per shift is also cut in half by the duration of regular work. Of course, this makes both the owner and employee disadvantaged.

Yogyakarta is known as students and tourist city also one of the provinces that affected by COVID-19, with the number in Yogyakarta on Wednesday (6/10/2020) positive being confirmed 250 people, 8 people died, and recovered 194. In a way, the positive confirmed number for COVID-19 is quite small compared to other cities that have even issued regulations on the Large-Scale Social Restrictions (PSBB). Indeed, with the low death rate too, the Yogyakarta government cannot give options to people in Yogyakarta to be free to do things as usual without regard to health protocols. The Yogyakarta government also echoes to Stay at Home. To overcome the spread of Covid-19, the Indonesian government implemented a number of policies such as maintaining physical distance and maintaining distance in communicating with the surrounding social environment as well as people being asked to avoid gathering and being in a crowd and recommended to be at home as much as possible, or we can call it as social grouping because a single social grouping policy can cut the spread of the epidemic (Chen et al., 2020).

Many areas in Indonesia are vulnerable to disasters, such as earthquakes, tsunamis, volcanic eruptions, long droughts, and various events beyond the control of a tourism business company (Bong, 2019).

On Saturday, May 27, 2006, when an earthquake shake up Yogyakarta. Based on the results of the mapping of earthquake-prone areas by E.K. Kertapati (2001) in the Departemen Energi dan Sumber Daya Mineral (2007), Yogyakarta and surrounding areas including seismic regions with the Modified Mercalli Intensity (MMI) V-VI Scale Intensity. The earthquake disaster in Yogyakarta still has the potential to continue to occur. This is because the area of Yogyakarta and its surroundings is located on a fault line controlled by plate tectonics. The activity of an earthquake is influenced by energy balance due to the dynamics of the earth's crust movement in the form of the movement of the Australian plate, which strikes the Eurasian plate (Prasetyadi, 2009; Soetadi, 1978). The Yogyakarta and the surrounding area geologically a wave propagation area/earthquake source force from a very old fault collapse ( 2 million years old) located $10 \mathrm{KM}$ east of the Opak 
fault with parallel orientation. The local geological complexity makes the earthquake waves of this anonymous nameless fault propagate to the Opak fault system and the Bantul (graben) system and also to the Dengkeng (Baturagung) fault system in southern Klaten. This earthquake wave propagation caused severe damage (damage belt) extending from Bantul to Klaten. Fractures or fault structures are weak areas that are most vulnerable to earthquake tremors.

In that situation, the earthquake, which was centered in Bantul at a depth of approximately $10 \mathrm{~km}$ that lasted around 57 seconds with 6.2 Scale Richter, not only brought down hundreds of buildings but also killed thousands of people, recorded 5,800 people die. The tragic event became the worst tragedy that ever happened in Yogyakarta. Nevertheless, tourism in Yogyakarta is having a hard hit. Prambanan Temple was damaged quite badly and temporarily closed to be examined the level of damage again. Yogyakarta Palace was badly damaged; the Trajumas ward, which became a symbol of justice, collapsed. As was as Imogiri's Tomb, some graves in Imogiri have collapsed, cracked floors, some walls and tomb buildings were fallen, as well as decorations such as broken ceramics. The closure of Adisutjipto Airport compounded this damage because the runway was broken.

At that time, the Yogyakarta Ministry of Culture and Tourism lost an income of around one billion dollars. Yogyakarta tourism at that time was devastated, but not for long. In Baiquni's calculation, the Yogyakarta tourism "rest" period after the earthquake only lasted for six months. Afterward, Yogyakarta tourism will be stretched again. Wardiyanto \& Baiquni (2011) also noted how the ingenuity of the citizens of Yogyakarta in packaging tourism. That is called disaster tourism, did in Yogyakarta. For example, the number of tourism entrepreneurs who make Merapi tours. Also, with the Mount Merapi Museum or local residents who opened a coffee shop at the foot of Merapi.

From the explanation above, this study will seek and find out the answer to two questions: 1. What is the effect of the COVID-19 virus on Tourism Attraction in Yogyakarta? 2. Is the impact of the COVID-19 virus on Tourism Attraction in Yogyakarta a more serious impact than an earthquake in 2006? A few researchers focused on the impact of COVID-19 in the economic sector without no comparison with other subjects. Then, there have been limited studies concerned on the different implications of COVID-19 and earthquake disaster in 2006 at Yogyakarta. Therefore, this research intends to compare a virus, and an earthquake can affect the whole system of a government, society, and economy.

\section{METHODOLOGY}

This research tries to compare the difference between COVID-19 and earthquake disaster that caused the Yogyakarta tourism industry to stop. The data was taken from journals, books, websites, government documents, and any other sources or articles. In this research, the researcher uses library research that is in the process of taking data; it does not need to go directly into the field but take various sources of reference that support this research. According to Sugiyono (2005) the descriptive qualitative method is a method used to describe or analyze a research result but is not used to make broader conclusions. The problem that can be investigated by qualitative descriptive research refers to quantitative studies, comparative studies (comparisons), and can also be a correlational study 
(relationship) between one element with other elements. Data collection techniques are studying and recording important information in conducting data analysis through data reduction, data display, and conclusions to get a picture of the findings of the study of literature to be developed in this study and to validate the data using triangulation of data sources.

\section{RESULTS AND DISCUSSION}

The Special Region of Yogyakarta is a Special Region at the provincial level in Indonesia, which is the fusion of the Sultanate of Yogyakarta and the Paku Alaman Duchy. The Special Region of Yogyakarta is located in the southern part of the island of Java and is bordered by the Provinces of Central Java and the Indian Ocean. The Special Region, which has an area of 3,185.80 km2 consists of one city, and four districts, According to the 2019 population census it has a population of $7,685,864$. Yogyakarta has always been a destination for domestic and foreign tourists, and this is evidenced by the award as a city that has the best service and favorite city in the top four in Indonesia. Yogyakarta also still holds the title of "tourism city," which is ranked number two after Bali (Syakdiah, 2017).

Faulkner (2001), in "Towards a Framework for Tourism Disaster Management", divides two types of tragedies in the tourism corridor: crisis and disaster. In simple terms, a crisis can be interpreted as an event caused by humans. This can refer to terrorism (the Bali bombing incident), to the Chernobyl tragedy, and even the transmission of viruses such as COVID-19 now. At the same time, disasters are natural phenomena that appear suddenly, ranging from hurricanes, landslides, tsunamis, as well as earthquakes. In this case, Yogyakarta already got two types of Tourism Disaster, and it will be discussed in this research.

With the temporary termination of the world as a result of COVID-19, all sectors stopped and could not work. The impact of COVID-19 on the Indonesian economy today with various impacts that occur on the economy due to the COVID19 pandemic which is the difficulty in finding employment, it is difficult to supply the needs of daily life and also have no income to meet their daily needs and also many hardships received from all sectors of the economy in all fields felt the impact of COVID-19. The clearer ones are that the economic sector is not spinning as it should be and cause many people cannot work and cannot make money. Also, there will be much starvation can occur due to lack of funds. The government is trying to provide various assistance ranging from cash to groceries. Yogyakarta's Tourism Office, on April 16, 2020, said the estimated loss of the tourism sector in DIY almost touched the Rp 81 billion. All because of the COVID-19 outbreak. The estimation arises from the data collection of dozens of types of businesses and hundreds of the kinds of tourism service businesses affected by the COVID-19 in Yogyakarta. Where the types of businesses and types of service businesses include formal and informal businesses. Besides, if in terms of human resources, those affected from 776 business services are 29,463 workers, as well as around 15 thousand laid-off workers. It is clear that COVID-19 is very detrimental to tourism in Yogyakarta, Prambanan Temple, which is one of the major temples in Yogyakarta, has also been badly affected by this COVID-19. During the three months that have been closed, since March 2020, the manager claimed to lose hundreds of billions. In addition, Prambanan Temple artists cannot do their work as usual and do not get income. But the manager of Prambanan Temple handed over 
basic food assistance to the artists at Prambanan Temple so that they could survive in the midst of the COVID-19 pandemic.

In contrast to crises that can be prevented by appropriate mitigation, natural disasters are difficult to predict. Even if it can be predicted, humans only have, "... a little control", and minimize risk. Often, disasters come unpredictably. An earthquake is a type of disaster which, until now, cannot be predicted when it will occur. This makes handling post-disaster more difficult. Yogyakarta earthquake case can be used as an example. In the World Bank report on the impact of the 2006 earthquake, PT TWC, a state-owned company, was significantly affected. PT TWC estimates that the total damage to the Prambanan facility was Rp 2,835 billion, and losses due to a decrease in visitors, Rp 1,151 billion per month in 2006. According to Winarsih (2007), the earthquake disaster of May 27, 2006, resulted in a significant decrease in the number of visitors by $658 \%$. After eight years of handling by using a method of consolidation or strengthening the structure of the building, the famous temple with the legend of Roro Jonggrang can be enjoyed again, including the largest temple building, the Shiva Temple. Specifically, for repairs at the Shiva Temple, the restoration has been completed since 2014.

Then, this COVID-19, which has been running since December 2019 until now June 8, 2020, "only" made a loss of about 81 billion. If calculated, the number of losses due to the earthquake is still 35 times compared to COVID-19. Although, an earthquake that can devastate Yogyakarta in less than one minute and cause death to thousands of people, can still be rebuilt even though it takes a long time, but has the certainty that Yogyakarta will be rebuilt as before. In contrast to COVID-19, which has no clarity when it will end, plus now many people are bored at home, then start doing activities that are less important and can cause transmission of COVID-19 to become more widespread.

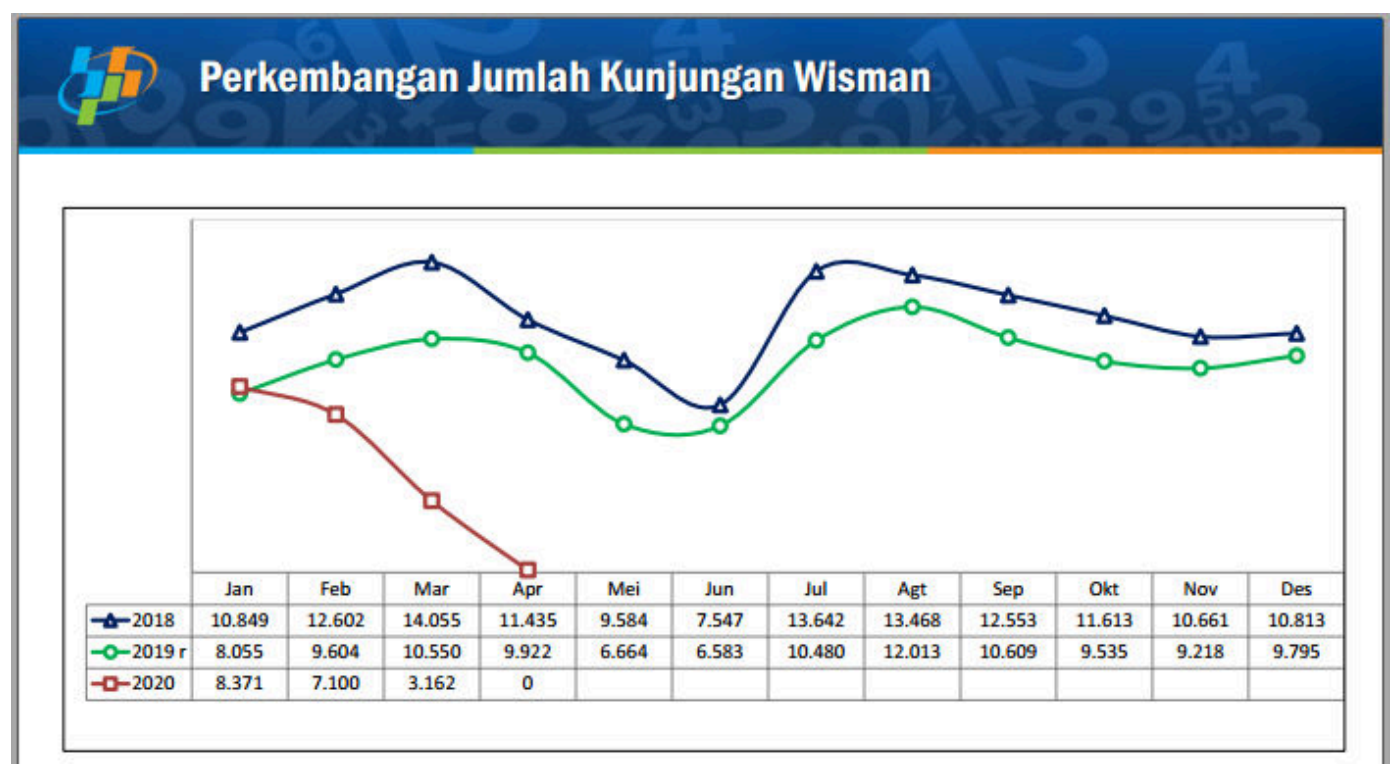




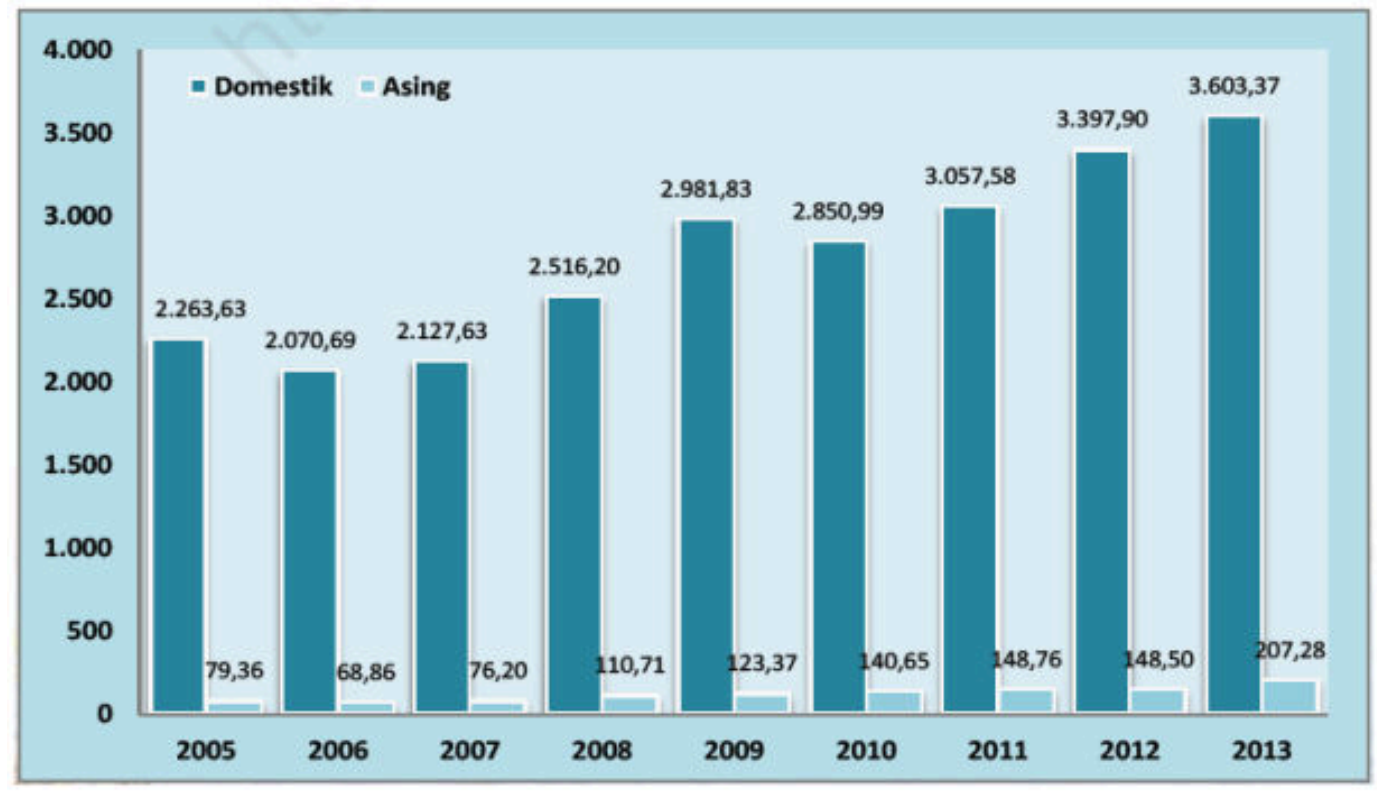

Source: BPS Yogyakarta (2020)

In 2006, the number of domestic tourists decreased from the previous year due to the earthquake by 1.92 million people and foreign tourists by 105 thousand people. This tourist reduction certainly has an impact on the owners of the industry in the field of tourism. Meanwhile, starting from December 2019 until March 2020, the decline in foreign tourists continued to occur until April 2020, none of the tourists came. This tourist reduction also happens because of the government's policy not to make tourist visits to other regions. If seen from the data and results that have been described above, the 2006 Yogyakarta earthquake that occurred during 57 seconds, caused huge losses and took a long time to reshape the tourism climate in Yogyakarta, moreover many tourist buildings such as Prambanan Temple that needed time up to 8 years for repairs. However, the big earthquake was not included as a national disaster but was quickly resolved because of the almost zero polemics, especially those made by those with political motives.

Then, the researcher tries to answer these two question, that was the aim of this study,

1. What is the effect of the COVID-19 virus on Tourism Attraction in Yogyakarta? The cessation of the tourism industry, creating a massive effect and producing a lot of losses for the owner, employees, and the tourist site itself. With no income from tourists, there is no cost for maintenance and for paying the employees.

2. Is the impact of the COVID-19 virus on Tourism attraction in Yogyakarta has a more severe impact than an earthquake in $2006 ?$

COVID-19 has a more significant impact than the 2006 Yogyakarta earthquake. It can be seen from the cessation of business in tourism for up to 3 months with little or no income and coupled with government regulations that forbid travel, making this tourism worse off. COVID-19 forbids people from leaving the house, and the tourist attractions become abandoned, due to the lack of income and lack of human resources to care for the tourism attractions. Although 
the Yogyakarta earthquake at the time caused damage to the building and the place, it could overcome quickly because the people worked together to fix their territory.

\section{CONCLUSION}

It can be concluded that COVID-19, as a human disaster, can make a significant impact on all sectors, especially for the tourism industry. It cannot be separated from human discipline to end the pandemic. As obey as humans follow the rules from the government, sooner the pandemic end. Same during earthquake tragedy, humans should work together to quickly resolve disasters and start cleaning up so they can quickly carry out normal activities.

\section{REFERENCES}

Bong, S. (2019). Manajemen Risiko, Krisis, Dan Bencana Untuk Industri Pariwisata Yang Berkelanjutan. Gramedia Pustaka Utama.

BPS Yogyakarta. (2020). Jumlah Penduduk menurut Kabupaten/Kota di D.I Yogyakarta (Jiwa), 2010-2019. https://yogyakarta.bps.go.id/dynamictable/2017/08/02/32/jumlahpenduduk-menurut-kabupaten-kota-di-d-i-yogyakarta-jiwa-.html

Chen, S., Yang, J., Yang, W., Wang, C., \& Bärnighausen, T. (2020). COVID-19 control in China during mass population movements at New Year. The Lancet, 395(10226), 764-766.

Departemen Energi dan Sumber Daya Mineral. (2007). Atlas Geologi Lingkungan Provinsi Daerah Istimewa: Peta Kegempaan. Departemen Energi dan Sumber Daya Mineral (ESDM).

Faulkner, B. (2001). Towards a framework for tourism disaster management. MD: National Emergency Training Center.

Huang, C., Wang, Y., Li, X., Ren, L., Zhao, J., Hu, Y., Zhang, L., Fan, G., Xu, J., Gu, X., Cheng, Z., Yu, T., Xia, J., Wei, Y., Wu, W., Xie, X., Yin, W., Li, H., Liu, M., ... Cao, B. (2020). Clinical features of patients infected with 2019 novel coronavirus in Wuhan, China. The Lancet, 395(10223), 497506. https://doi.org/10.1016/S0140-6736(20)30183-5

Prasetyadi, C. (2009). Principles of Plate Tectonics \& Structural Geology. Materi dari Kursus Geology for Nongeologist. Yogyakarta: Ikatan Ahli Geologi Indonesia - Pengurus Daerah Istimewa Yogyakarta.

Soetadi. (1978). Gempa Bumi. Duta Bina Pustaka.

Sugiyono. (2005). Metode Penelitian Administrasi. Alfabeta.

Syakdiah. (2017). Dinamika Pariwisata Daerah Istimewa Yogyakarta. Prosiding Seminar dan Call For Paper, 225-233.

Wardiyanto, \& Baiquni. (2011). Perencanaan Dan Pengembangan Pariwisata. Lubuk Agung.

Winarsih, D. (2007). Usaha PT Taman Wisata Candi Borobudur, Prambanan dan Ratu Boko Untuk Menarik Wisatawan ke Candi Prambanan Pasca Gempa 27 Mei 2006. Universitas Sebelas Maret. 